\title{
LOGIT MODEL OF MOTORCYCLE ACCIDENTS IN THE PHILIPPINES CONSIDERING PERSONAL AND ENVIRONMENTAL FACTORS
}

\author{
Rosemary R. Seva ${ }^{1}$, Glaiza Marie T. Flores ${ }^{2}$, Maria Patricia T. Gotohio ${ }^{3}$, \\ Noel Gabriel C. Paras ${ }^{4}$ \\ 1,2,3,4 Human Factors and Ergonomics Center, Industrial Engineering Department, De La Salle University, \\ 2401 Taft Avenue, Malate, Manila
}

Received 4 October 2012; accepted 12 March 2013

\begin{abstract}
The study aims to determine significant personal and environmental variables in predicting motorcycle accidents in the Philippines, compare the results with findings in other countries, and propose possible government interventions. Data were gathered from 177 participants through the use of a survey in a licensing center in the largest city in Metro Manila. Logistic regression was used to predict the likelihood of an accident from variables considered in the model. Three variables were found to be significant predictors of motorcycle accidents: age, driving behavior, and junction type. Younger drivers are more likely to be involved in accidents. The significance of age was unexpected because similar models found this to be insignificant. Driving behavior, specifically, committing violation predicts accident likelihood. Driving at t- and y-junctions also predicts motorcycle accidents. In the Philippines, a unique set of variables were found to predict motorcycle accidents. Although previous studies have established the effect of these variables to accident likelihood, the combination was unforeseen. Government agencies can focus on interventions directed at these three variables.
\end{abstract}

Keywords: motorcycle accidents, personal variables, environmental variables, logistic regression.

\section{Introduction}

The increasing price of gasoline and traffic jams on the road made the motorcycle (MC) a popular choice of transportation in the Philippines in recent years. The number of registered MC's in the Philippines doubled from 2003 reaching a total of 3.2 million in 2009 (Abelgas, 2010). As its popularity increases, however, the number of accidents related to it also exhibited an increasing trend.

In 2007, the Department of Health reported that the mortality rate from $\mathrm{MC}$ accidents has reached an alarming rate (Andrade, 2007). Victims of accidents on the road represent
$30-86 \%$ of patients admitted for trauma in hospitals (De Leon et al., 2005). In one of the biggest public hospitals in the capital city of the Philippines (UP-PGH), 25\% of medicolegal cases involved vehicular collisions. The Philippine National Police (PNP) also expressed concern regarding the increasing trend in MC accidents indicating that in January 2010 alone, 209 cases of accidents have already been recorded (Abelgas, 2010).

Although accidents involving motorcycle (MC) in the Philippines continue to increase, only a few studies have been done to investigate its causes and identify possible interventions to mitigate the situation. The same situation

\footnotetext{
${ }^{1}$ Corresponding author: rosemary.seva@dlsu.edu.ph
} 
is true for other developing countries in the ASEAN region. Accident data obtained by the government were not processed for the purpose of statistical analysis and prediction (Asian Development Bank, 2005a). The National Center for Transportation Studies of the University of the Philippines investigated the causes of accidents in Commonwealth Avenue in Quezon City where accidents are likely to occur (Libres et al., 2008). The study, however, did not seek to predict accidents and considered all types of vehicles and was limited to only one road as mentioned. The only variable studied is driver characteristic which is just one of the factors influencing accidents. Although there have been some studies in other countries correlating environmental and personal variables to accidents the methods used are descriptive in nature. Studies done in Thailand (Stephan et al., 2011), Vietnam (Hsu et al., 2003), Taiwan (Chang and Yeh, 2007), Malaysia (Hsu et al., 2003), Germany (Wick et al., 1998), Denmark (Barsi et al., 2002) and France (Moskal et al., 2012) only showed descriptive statistics of the variables considered and did not seek to determine which of them are significant predictors of accident. Prediction models developed in Indonesia (Indriastuti and Sulistio, 2010), and Iran (Majdzadeh et al., 2008) considered accident prediction but the variables included are very limited. Haque et al. (2012) considered roadway characteristics, traffic control measures and environmental variables in Singapore and their association with $\mathrm{MC}$ crashes but did not take into account their interaction with personal variables. Other models developed in literature did not consider accident likelihood but accident severity (Yannis et al., 2005; Huang et al., 2008) and fatality (Yau, 2004).

Conclusions from accident studies in other countries especially developed ones may not be directly applicable to a developing country like the Philippines due to its uniqueness in terms of road quality, driver behavior and safety culture. Compared to its Asian counterparts, the Philippines has a very low percentage of roads in good condition and only $20 \%$ of roads are paved (World Bank, 2009). The implementation of traffic laws is lax and road users are not disciplined. The same trend may be observed in other developing countries such as Indonesia and Vietnam (Asian Development Bank, 2005a; Asian Development Bank, 2005b; Asian Development Bank, 2005c). As such, MC drivers in these countries encounter more and unique challenges than drivers in developed countries. Driving constraints are also distinct for a particular country.

In Hongkong, for instance, Yau (2004) investigated five groups of variables that influence fatality of MC accidents, namely; region, traffic condition, human, vehicle, and environment. It was discovered that the day of the week and time of the accident determine the severity of crashes. This result may not be comparable to the Philippines because in Hong Kong MC drivers mainly drive on weekends whereas in the Philippines and other developing countries MC drivers use the vehicle every day so it is likely that the time of the week may not be a significant predictor of accident.

In a related study of Yau et al. (2006) good lighting condition at night was associated to severe vehicle crashes, which is unexpected. This unusual result was attributed to greater cautiousness of drivers when streets are unlighted especially at night. Pai and Saleh (2008), however, had contrasting findings in UK where unlit street lights showed increased chance of accident severity. These contrasting findings warrant further 
investigation on the matter. Drivers' reaction to environmental stimuli may differ based on the context.

In the Philippines, accidents are documented through the police report form that includes environment and driver dependent variables (Flores et al., 2011). Environmental variables are conditions that potentially influence the performance of the MC driver but are uncontrollable such as street lighting, surface conditions, and road character while personal variables are usually driver characteristics such as gender, age, and behavior. The Asian Development Bank (2005a) has conducted several studies that characterized accidents in terms of these variables but accident likelihood was not predicted. As such, the reports have not identified which ones are significant in predicting $\mathrm{MC}$ accidents in similar developing countries such as Vietnam and Indonesia.

This study aims to identify significant personal and environmental variables in predicting MC accidents in a developing country like the Philippines because it is posited that significant predictors will be different from those obtained in studies done in other countries. The difference may be brought about by distinct road conditions, driver behavior, and safety culture. The outcome of this investigation may be used by other developing countries in improving their safety programs and help focus government efforts on dominant predictors of MC accidents.

\section{Research Method}

\subsection{Variables and Measurements}

In this study the dependent variable is the occurrence of accident which is a binary variable. The value of the variable is 1 if the participant surveyed encountered an accident and 0 if it is a near miss.

Several independent variables were considered as predictors of accidents as enumerated in Table 1 . These variables were chosen because they are related to policy making on MC driving. Driving behavior, although not subsumed by public policy is influenced by it so it was likewise investigated.

Table 1

Model Variables

\begin{tabular}{|l|l|l|}
\hline Independent Variables & Variable Code & Variable settings \\
\hline 1. Age & A & Years \\
\hline 2. Lighting Conditions & LC & $\begin{array}{l}1=\text { Daylight; } 2=\text { Dawn*; } \\
\text { 3 = Night with Light; } 4=\text { Night without Light }\end{array}$ \\
\hline 3. Traffic Movement & TM & $1=$ One-way*; $=$ Two-way \\
\hline 4. Road Character & RC & $1=$ Straight; $2=$ Curve*; $3=$ Inclined \\
\hline 5. Junction Type & JC & $\begin{array}{l}1=\text { Not at Junction; } 2=\text { T-Junction; 3 = Intersection* } \\
\text { 4= Multiple Junction 5 = Y-Junction; } \\
6=\text { Roundabout; } 7=\text { Other }\end{array}$ \\
\hline 6. Day & D & $1=$ Weekday*; $=$ Weekend \\
\hline 7. Surface Conditions & SC & $1=$ Dry*; $2=$ Wet \\
\hline 8. Driving Behavior & DB & $\begin{array}{l}1=\text { Aggressive*; } 2=\text { Ordinary Violation; } \\
\text { 3= Error; } 4=\text { Lapse }\end{array}$ \\
\hline
\end{tabular}

${ }^{*}$ Reference category for categorical independent variables 
Age the only numerical variable in the model is quantified in years. The remaining variables such as lighting conditions, traffic movement, road character, junction type, day, surface condition, and driving behavior are all categorical and were coded in the model. The settings of these variables were adapted from literature and data gathered from surveys done in the Philippines.

Driving behavior was assessed using a modified version of the Manchester Driver Behavior Questionnaire (DBQ) where the final results reveal the driving behavior as aggressive violation, ordinary violation, error, and lapse. Violations refer to disregard of rules. These violations can be ordinary or aggressive with an intention to hurt others. Errors are actions that were not planned and related to failures of observation and judgment while lapses refer to failures in memory and attention (Davey et al., 2007; Lajunen and Summala, 2003). The questions used were modified to facilitate understanding of the participants and translated in the local language. Only questions applicable in the context of MC driving were used as part of the data gathering. Questions for driver behavior were rated according to a frequency scale (1-lowest up to 5 highest).

For the other factors considered in the study, multiple-choice questions were formulated with the variable levels as choices. The first question specifically asked if the participant had been involved in a MC accident.

\subsection{Participants}

Motorcyclists renewing their license in the Land Transportation Office (LTO) were recruited as survey participants. No specific age range was targeted; all motorcyclists encountered were asked to answer the survey since age was also considered in analyzing the occurrence of MC accident. In addition, all participants have at least three-year experience of driving because their licenses are subject for renewal which is done every three years. Driving experience served as screening variable for participants and had minimal variation among motorcyclists. Considering the screening criteria used in the study, only $70 \%$ of MC drivers renewing their license is qualified. About $80 \%$ of qualified MC drivers participated in the survey. The other $20 \%$ did not participate due to time constraints.

\subsection{Procedure}

A survey was conducted at the Renewal Licensing Center of the Land Transportation Office (LTO) where MC drivers renew their license. All licenses subject for renewal were checked to determine if the driver uses a MC. Identified MC drivers were courteously asked if they want to participate in the survey. They were assured that their answers will be kept confidential. Since it was desired to model accident likelihood among MC drivers in the Philippines using logistic regression, data were obtained from two groups of MC drivers: those who had accidents and without accidents. Drivers who agreed to participate in the survey were asked to recall a MC accident they encountered in the past. In case they have been involved in multiple MC accidents, they were asked to recall the most recent one when they answer the survey. If the participant did not encounter any accident, they were asked to recall a "near miss". In this study, a nonaccident event is defined as a near miss which is a situation when the driver almost experienced an accident. Just like an accident, a near miss is memorable to the driver and as such s/ he can still recall the details of the situation. The definition of a near miss incident was clarified to the participants before the survey. A briefing script was used to ensure uniformity in providing information. In case they had many 
near misses they were asked to recall the most recent near miss experienced. Drivers who did not have accidents or near misses were excluded from the survey. One hundred seventy-seven (177) drivers participated in the survey, 78 of which experienced accidents and the other 99 experienced near-misses.

All willing participants were given a survey form to answer. Before allowing the participant to leave, the survey was checked to ensure that all questions were answered properly. No time limit was given to avoid any pressure.

\subsection{Statistical Model}

Logistic regression was used in predicting the chance of accidents. It is a technique used to predict a dependent variable on the basis of continuous and/or categorical independents. The general purposes of logistic regression, which are: to determine the effect size of the independent variables on the dependent variable, rank the relative importance of independents and, understand the impact of covariate control variables (DeMaris, 1992).

Logistic regression predicts the log odds of the dependent event. The "event" is a particular value of $y$, which is the dependent variable. By default, the event is $y=1$ for binary and the reference category is 0 . The logistic regression equation is expressed in Eq. (1) as:

$g(x)=\beta_{0}+\beta_{1} X_{1}+\beta_{2} X_{2}+\ldots \beta_{n} X_{n}$

where,

$g(x)=$ the log odds of the dependent variable.

Individual predictors of the model were tested using Wald's test while the goodness of fit of the model obtained was assessed using HosmerLemeshow (HL) test which follows a chi- square distribution. Large p-value for the HL test indicates model significance which means the logistic model may be used to predict actual outcomes (Hair et al., 2010). A more detailed discussion of logistic regression may be found in Al-Ghamdi (2002).

\section{Results}

\subsection{Descriptive Statistics}

The average age of participants is 35 years. The youngest is 20 and the oldest is 62 . There were 78 participants who encountered accidents (A) and 99 with near misses coded as "no accident" (NA) for a total of 177. Participants' profile in terms of the independent variables investigated can be seen in Table 2 .

Based on gathered data, accidents were more prevalent on weekdays and daytime. They are also likely to happen at dry and straight roads. Consistent with expectations, drivers that exhibit aggressive behavior are usually involved in accidents. The presence of T-junctions and no-junctions contribute more to accidents although there were more accidents in T-junctions.

\subsection{Model Development}

The effects of environment and personal variables to accidents were modeled using logistic regression. Variables were tested for multicollinearity but none of them were found to be correlated. All the explanatory variables were fitted into the model with no interactions at first (saturated model) and then reduced to include only variables that were found to be significant. Based on the results of the logistic regression, significant variables found were age $(p<0.1)$, driver behavior and junction type $(p<0.05)$ while controlling for other variables. Wald statistic was computed as it is 
Table 2

Participants' Profile

\begin{tabular}{|c|c|c|c|}
\hline Variables & No Accident (99) & Accident (78) & Total (177) \\
\hline \multicolumn{4}{|l|}{ Road condition } \\
\hline Straight & $33 \%$ & $28 \%$ & $61 \%$ \\
\hline Curved & $15 \%$ & $12 \%$ & $27 \%$ \\
\hline Inclined & $8 \%$ & $4 \%$ & $12 \%$ \\
\hline \multicolumn{4}{|l|}{ Traffic movement } \\
\hline 1 way & $15 \%$ & $13 \%$ & $28 \%$ \\
\hline 2 way & $41 \%$ & $31 \%$ & $72 \%$ \\
\hline \multicolumn{4}{|l|}{ Lighting condition } \\
\hline Daylight & $27 \%$ & $24 \%$ & $51 \%$ \\
\hline Dawn & $3 \%$ & $4 \%$ & $7 \%$ \\
\hline Night with light & $17 \%$ & $9 \%$ & $26 \%$ \\
\hline Night without light & $8 \%$ & $8 \%$ & $16 \%$ \\
\hline \multicolumn{4}{|l|}{ Surface condition } \\
\hline Dry & $33 \%$ & $29 \%$ & $62 \%$ \\
\hline Wet & $23 \%$ & $15 \%$ & $38 \%$ \\
\hline \multicolumn{4}{|l|}{ Day of the week } \\
\hline Weekday & $35 \%$ & $31 \%$ & $66 \%$ \\
\hline Weekend & $21 \%$ & $14 \%$ & $34 \%$ \\
\hline \multicolumn{4}{|l|}{ Junction type } \\
\hline Not at junction & $19 \%$ & $16 \%$ & $35 \%$ \\
\hline T-junction & $12 \%$ & $18 \%$ & $30 \%$ \\
\hline Intersection & $9 \%$ & $3 \%$ & $12 \%$ \\
\hline Multiple junction & $3 \%$ & $2 \%$ & $5 \%$ \\
\hline Y-junction & $2 \%$ & $3 \%$ & $5 \%$ \\
\hline Roundabout & $4 \%$ & $1 \%$ & $5 \%$ \\
\hline Other & $6 \%$ & $2 \%$ & $8 \%$ \\
\hline \multicolumn{4}{|l|}{ Driving behavior } \\
\hline Aggressive & $16 \%$ & $16 \%$ & $32 \%$ \\
\hline Ordinary & $6 \%$ & $10 \%$ & $16 \%$ \\
\hline Error & $8 \%$ & $6 \%$ & $14 \%$ \\
\hline Lapse & $25 \%$ & $12 \%$ & $37 \%$ \\
\hline
\end{tabular}


the counterpart of t-test in logistic regression. It gives the statistical significance of each coefficient (Hair et al., 2010). Based on Wald's test, the coefficients of age, lapse, no-junction, T-junction, and Y-junction are significant. The estimated coefficients, standard error, odds ratio, and Wald's statistic are shown in Table 3.

Interaction between variables was explored in this study based on literature and unique driving situations in the Philippines. Interactions were investigated by adding possible interaction terms to the full model (with three significant variables). If the interaction is significant, the deviance of the interaction model should be significantly large at 0.05 level. One interaction explored after deriving the reduced model is between age and junction type because older drivers although well-experienced tend to have problems perceiving approaching vehicles at junctions (Clarke et al., 2004). This may be attributed to a decrease of perceptive ability brought about by age. The interaction, however, was not found to be significant $(p=0.51)$ based on the $\chi^{2}$ test of deviance.

The interaction between age and driving behavior was also investigated because younger drivers tend to exhibit risky behavior in the Philippines as in other countries (Chang and Yeh, 2007). The interaction term was also found to be insignificant $(p=0.80)$. Thus, all interaction terms were not included in the final model.

Table 3

Estimated Coefficients, Standard Error, Wald Statistic and Odds Ratios of Reduced Logit Model

\begin{tabular}{|c|c|c|c|c|c|}
\hline Variable & $\begin{array}{c}\text { Estimated } \\
\text { Coeff }\end{array}$ & Std Error & p-value & Odds Ratio & Wald's \\
\hline Age (A) & -0.036 & 0.017 & 0.038 & 0.96 & -2.118 \\
\hline Error (DB2) & -0.496 & 0.54 & 0.359 & 0.61 & -0.919 \\
\hline Lapse (DB3) & -0.97 & 0.414 & 0.019 & 0.38 & -2.343 \\
\hline $\begin{array}{l}\text { Ordinary } \\
\text { violation } \\
\text { (DB4) }\end{array}$ & 0.530 & 0.511 & 0.300 & 1.70 & 1.037 \\
\hline Multiple (JT2) & 1.145 & 0.887 & 0.197 & 3.14 & 1.291 \\
\hline $\begin{array}{l}\text { No junction } \\
\text { (JT3) }\end{array}$ & 1.361 & 0.604 & 0.024 & 3.90 & 2.253 \\
\hline Other (JT4) & 0.318 & 0.862 & 0.712 & 1.37 & 0.369 \\
\hline $\begin{array}{c}\text { Roundabout } \\
\text { (JT5) }\end{array}$ & -0.913 & 1.198 & 0.446 & 0.40 & -0.762 \\
\hline $\begin{array}{l}\text { T-junction } \\
\text { (JT6) }\end{array}$ & 1.796 & 0.61 & 0.003 & 6.03 & 2.944 \\
\hline $\begin{array}{l}\text { Y-junction } \\
\text { (JT7) }\end{array}$ & 1.835 & 0.913 & 0.044 & 6.27 & 2.010 \\
\hline Constant & 0.182 & 0.818 & & & \\
\hline
\end{tabular}




\subsection{Logit Model}

Based on the previous analysis, the logit model with the significant terms is shown in Eq. (2) as follows:

$$
\begin{aligned}
g(x)= & 0.18-0.04(A)-0.50(D B 2)-0.97(D B 3)+0.53(D B 4)+1.14(J T 2) \\
& +1.36(J T 3)+0.32(J T 4)-0.91(J T 5)+1.80(J T 6)+1.84(J T 7)
\end{aligned}
$$

\section{Discussion}

This study only considered MC accidents that occurred and reported in Quezon City, Philippines. Three variables were found to be significant in predicting the likelihood of MC accidents: age, driving behavior, and junction type. Based on the negative parameter estimate obtained for age, younger drivers are more likely to be involved in accident which is consistent with majority of accident studies. The significance of age may be attributed to young drivers' higher tendency for engaging in risky behaviors such as speeding and overtaking. The significance of age as an accident predictor warrants further investigation. It is crucial to know unique behavioral characteristics of young Filipino MC drivers that influence accident occurrence which is not observable in other countries.

Among the variables included in this study, age is one that is not affected by economic and political factors related to a country. The significance of age in the current model was unexpected since accident prediction models obtained in other developing countries such as Indonesia (Indriastuti and Sulistio, 2010) and Iran (Majdzadeh et al., 2008) considered age as an independent variable but turned out to be statistically insignificant. The influence of age in previous studies was overshadowed by other variables such as gender, behavior and driving knowledge which were not included as variables in the current study.
Driving behavior was also found to be a significant predictor of MC accidents. The base level used in the model is aggressive behavior and as can be seen in Table 3, lapse is the most significantly associated with $\mathrm{MC}$ accident although its odds ratio is only 0.38. Lapse is defined as an action done related to attention and memory failures (Lajunen and Summala, 2003). The small odds ratio indicate that accident is less likely to occur if driving behavior is characterized by lapses. Ordinary violation has the highest odds ratio at 1.7 indicating that the odds of encountering a $\mathrm{MC}$ accident due to ordinary violation are 1.7 higher than aggressive violation. Violation has been defined by Reason et al. (1990) as "deliberate deviations from those practices believed necessary to maintain the safe operation of a potentially hazardous system". Based on data gathered by the MMDA in 2005 and 2006 the most common cause of MC accidents is speeding violation followed by inattentiveness (Metro Manila Development Authority, 2009). Literature on the use of the Driver Behaviour Questionnaire documented the prevalence of violations rather than errors in the occurrence of crashes (Lajunen et al., 2004). In Taiwan, a similar study showed that negligence of potential risk and violation are associated with increased accident (Chang and Yeh, 2007) while in Indonesia disobedience to traffic rules was not a significant accident predictor. The foregoing comparison with other studies suggests that violation and lapses are important predictor of $\mathrm{MC}$ accidents both 
in developed and developing countries with the exception of Indonesia.

Junction type was also found to be significant in MC accidents in the Philippines especially at $\mathrm{T}$ - and $\mathrm{Y}$-junctions. This may be attributed to the problem of not perceiving a $\mathrm{MC}$ while turning at a junction especially if the automobile driver is in a hurry. Unlike in Malaysia (Radin et al., 1996) and Singapore (Wu, 2000) the Philippines has no daytime running headlight policy which aggravates the problem of seeing MC's during the day. Moreover, while driving in junctions, MC drivers need to skillfully maneuver the vehicle. Manoeuvring requires speed and accuracy of movement so as not to collide with oncoming vehicles. A driver who is not alert or inattentive tends to execute wrong motions that can lead to accidents. Crundall et al. (2008) found that when perception time is limited, a driver who looked may not see an oncoming $\mathrm{MC}$ from afar.

It is noteworthy that many variables were found to be insignificant in this study such as lighting condition, surface condition, road character, traffic movement, and day of the week although they figured to be significant in other studies. Their insignificance may be explained by the uniqueness of data obtained from the Philippines, the methodology employed, and the response variable in the model.

The hypothesis posited at the beginning of the paper was partially validated by the results obtained in the logistics regression. Since the p-values obtained for age and junction-type are less than 0.05 the alternative hypothesis that these two are significant predictors of accident likelihood is accepted. They are significant predictors of $\mathrm{MC}$ accidents in this study when they were found to be insignificant in similar models found in other countries. Only the effect of driving behavior was found to be consistent with similar prediction studies especially on violations.

The government can use the outcome of this study to propose new laws that will improve MC riding safety. Accidents in traffic junctions can be minimized by improving the conspicuity of MC drivers. Other countries have implemented the policy of running with headlights on but the Philippines failed to follow.

The use of speed cameras may also be considered at junctions to discourage drivers from speeding upon approach of the junction. The effectiveness of this measure was confirmed by a number of researchers in minimizing red light violations (Chin, 1989; Lum and Wong, 2003). The Philippine government can install speed cameras at a number of major intersections and gather data to evaluate its effectiveness in solving speeding problems and minimizing other traffic violations. If they are proven to be effective in modifying the behavior of drivers the government can invest in the installation of these cameras at all intersections especially those that have history of high incidence of accident.

\section{Conclusion}

The study modeled the likelihood of MC accidents using logistic regression. Results showed only three significant variables: age, driving behavior, and junction type. Unlike results obtained in other developing countries, age is an important factor for predicting MC accidents in the Philippines. Younger drivers are more likely to be involved in accidents. Although age had been considered in previous studies, it was not used to predict accidents. The finding about age may be used by the government to focus its efforts on intensively educating young drivers about road safety 
and the importance of following rules on the road.

Contrary to expectation, among the driving behaviors studied in the study aggressiveness did not contribute much to accident probability compared to lapses. There is a greater chance of accident at $\mathrm{t}$-junctions in particular because of the difficulty of movement and the failure of other motorists to notice MC drivers. Possible interactions were explored such as age and driving behavior, age and junction type, and driving behavior and junction type but did not show statistical significance. Thus, the effects of the significant factors obtained were interpreted independently.

\section{References}

Abelgas, G. 2010. Motorcycle accidents on the rise. Available from Internet: <http://www.abs-cbnnews. com/nation/metro-manila/02/18/10/motorcycleaccidents-rise $>$.

Al-Ghamdi, A.S. 2002. Using logistic regression to estimate the influence of accident factors on accident severity, Accident Analysis and Prevention. DOI: http:// dx.doi.org/10.1016/S0001-4575(01)00073-2, 34(6): 729-741.

Andrade, J. 2007. Motorcycle accidents have highest fatality rate - DOH, Philippine Daily Inquirer. September 20. Available from Internet: <http://newsinfo.inquirer. net/breakingnews/metro/view/20070920-89712/ Motorcycle_accidents_have_highest_fatality_rate-DoH_>.

Asian Development Bank. 2005a. Arrive alive: ASEAN commits to cutting road deaths. Manila, Philippines. $108 \mathrm{p}$.

Asian Development Bank. 2005b. ADB-ASEAN Regional Road Safety Program. Country Report: CR 3. Road Safety in Indonesia. Manila, Philippines. 27 p.
Asian Development Bank. 2005c. ADB-ASEAN Regional Road Safety Program. Country Report: CR 10. Road Safety in Vietnam. Manila, Philippines. 23 p.

Barsi, T.; Faegermann, C.; Larsen, B. 2002. Road Traffic Accidents with Two-Wheeled Motor Vehicles during a Five-Year Period in Odense, Denmark, Traffic Injury and Prevention. DOI: http://dx.doi. org/10.1080/15389580214621, 3(4): 283-287.

Chang, H.L.; Yeh, T.H. 2007. Motorcyclist accident involvement by age, gender, and risky behaviors in Taipei, Taiwan, Transportation Research Part F: Traffic Psychology and Behaviour. DOI: http://dx.doi.org/10.1016/j. trf.2006.08.001, 10(2): 109-122.

Chin, H.C. 1989. Effect of Automatic Red-light Cameras on Red-running, Traffic Engineering Control, 30(4): 175179.

Clarke, D.; Bartle, P.; Truman, W. 2004. In-depth study of motorcycle accidents. Department for Transport, London. 69 p.

Crundall, D.; Humphrey, K.; Clarke, D. 2008. Perception and appraisal of approaching motorcycles at junctions, Transportation Research Part F: Traffic Psychology and Behaviour. DOI: http://dx.doi.org/10.1016/j. trf.2007.09.003, 11(3): 159-167.

Davey, J.; Wishart, D.; Freeman, J.; Watson, B. 2007. An application of the Driver Behaviour Questionnaire in an Australian organisational fleet setting, Transportation Research Part F: Traffic Psychology and Behaviour. DOI: http://dx.doi.org/10.1016/j.trf.2006.03.001, 10(1): 11-21.

De Leon, M.R.; Cal, P.; Sigua, R. 2005. Estimation of socio-economic cost of road accidents in Metro Manila, Journal of the Eastern Asia Society for Transportation Studies, 6(2005): 3183-3198.

DeMaris, A. 1992. Logit modeling: Practical applications. Sage Publications USA. 87 p. 
Flores, G.M.; Gotohio, P.; Paras, N. 2011. Analysis of motorcycle accidents based on environmental and personal variables. In Proceedings of the 2 nd International Conference on Industrial Engineering and Operations Management.

Hair, J.F.; Black, B.; Babin, B.; Anderson, R.E.; Tatham, R.L. 2010. Multivariate Data Analysis. 7th ed. Prentice Hall USA. 116 p.

Haque, M.M.; Chin, H.C.; Debnath, A.K. 2012. An investigation on multi-vehicle motorcycle crashes using log-linear models, Safety Science. DOI: http://dx.doi. org/10.1016/j.ssci.2011.09.015, 50(2): 352-362.

Hsu, T.P.; Sadullah, A.F.M.; Dao, N.X. Nguyen Xuan Dao. 2003. Taiwan: National Taiwan University. 137 p.

Huang, H.; Chin, H.; Haque, M.M. 2008. Severity of driver injury and vehicle damage in traffic crashes at intersections: A Bayesian hierarchical analysis, Accident Analysis and Prevention. DOI: http://dx.doi.org/10.1016/j. aap.2007.04.002, 40(1): 45-54.

Indriastuti, A.K.; Sulistio, H. 2010. Influencing factors on motorcycle accident in urban area of Malang, Indonesia, International Journal of Academic Research, 2(5): 252-255.

Lajunen, T.; Parker, D.; Summala, H. 2004. The Manchester Driver Behaviour Questionnaire: a crosscultural study, Accident Analysis and Prevention. DOI: http://dx.doi.org/10.1016/S0001-4575(02)00152-5, 36(2): 231-238.

Lajunen, T.; Summala, H. 2003. Can we trust self-reports of driving? Effects of impression management on driver behaviour questionnaire responses, Transportation Research Part F: Traffic Psychology and Behaviour. DOI: http://dx.doi. org/10.1016/S1369-8478(03)00008-1, 6(2): 97-107.

Libres, G.T.C.; Galvez, M.L.I.; Cordero, C.J.N. 2008. Analysis of Relationship between Driver Characteristic and Road Accidents along Commonwealth Avenue: Department of Civil Engineering, University of the Philippines Diliman. 5 p.
Lum, K.M.; Wong, Y.D. 2003. Impacts of Red Light Camera on Violation Characteristics, Journal of Transport Engineering. DOI: http://dx.doi.org/10.1061/ (ASCE)0733-947X(2003)129:6(648), 129(6): 648-656.

Majdzadeh, R.; Khalagi, K.; Naraghi, K.; Motevalian, A.; Eshraghian, M.R. 2008. Determinants of traffic injuries in drivers and motorcyclists involved in an accident, Accident Analysis and Prevention. DOI: http://dx.doi.org/10.1016/j. aap.2007.03.019, 40(1): 17-23.

Metro Manila Development Authority. 2009. Motorcycle Traffic Accidents. Metro Manila Development Authority, Metropolitan Safety Unit. 17 p.

Moskal, A.; Martin, J.L.; Laumon, B. 2012. Risk factors for injury accidents among moped and motorcycle riders, Accident Analysis and Prevention. DOI: http://dx.doi. org/10.1016/j.aap.2010.08.021, 49(2012): 5-11.

Pai, C.W.; Saleh, W. 2008. Modelling motorcyclist injury severity by various crash types at $\mathrm{T}$-junctions in the UK, Safety Science. DOI: http://dx.doi.org/10.1016/j. ssci.2007.07.005, 46(8): 1234-1247.

Radin, U.R.S.; Mackay, M.G.; Hills, B.L. 1996. Modelling of conspicuity-related motorcycle accidents in Seremban and Shah Alam, Malaysia, Accident Analysis and Prevention, 28(3): 325-332.

Reason, J.T.; Manstead, A.S.R.; Stradling, S.G.; Baxter, J.S.; Campbell, K. 1990. Errors and violations on the road: a real distinction?, Ergonomics. DOI: http://dx.doi. org/10.1080/00140139008925335, 33(10-11): 13151332.

Stephan, K.; Kelly, M.; McClure, R. et al. 2011. Distribution of transport injury and related risk behaviours in a large national cohort of Thai adults, Accident Analysis and Prevention. DOI: http://dx.doi.org/10.1016/j. aap.2010.12.011, 43(3): 1062-1067.

Wick, M.; Müller, E.J.; Ekkernkamp, A.; Muhr, G. 1998. The motorcyclist: Easy rider or easy victim? An analysis 
of motorcycle accidents in Germany, The American Journal of Emergency Medicine. DOI: http://dx.doi.org/10.1016/ S0735-6757(98)90113-9, 16(3): 320-323.

World Bank. 2009. Philippines Transport for Growth: An Institutional Assessment of Transport Infrastructure, Manila. $130 \mathrm{p}$.

Yannis, G.; Golias, J.; Papadimitriou, E. 2005. Driver age and vehicle engine size effects on fault and severity in young motorcyclists accidents, Accident Analysis and Prevention. DOI: http://dx.doi.org/10.1016/j.aap.2004.10.003, 37(2): 327-333.

Wu, Y. 2000. The effectiveness of the 'ride-bright' legislation for motorcycles in Singapore, Accident Analysis and Prevention. DOI: http://dx.doi.org/10.1016/S00014575(99)00078-0, 32(4): 559-563.

Yau, K.K.W. 2004. Risk factors affecting the severity of single vehicle traffic accidents in Hong Kong, Accident Analysis and Prevention. DOI: http://dx.doi.org/10.1016/ S0001-4575(03)00012-5, 36(3): 333-340.

Yau, K.K.W.; Lo, H.P.; Fung, S.H.H. 2006. Multiplevehicle traffic accidents in Hong Kong. Accident Analysis and Prevention, 38(6): 1157-1161.

\section{LOGIT MODEL SAOBRAĆAJNIH NEZGODA SA MOTOCIKLISTIMA NA FILIPINIMA BAZIRAN NA PSIHOFIZIČKIM KARAKTERISTIKAMA VOZAČA I FAKTORIMA OKRUŽENJA}

\section{Rosemary R. Seva, Glaiza Marie T. Flores, Maria Patricia T. Gotohio, Noel Gabriel C. Paras}

Sažetak: U radu su prikazani rezultati studije koja je imala za cilj da utvrdi značaj psihofizičkih karakteristika vozača i faktora okruženja na predviđanje saobraćajnih nezgoda sa motociklistima na Filipinima, da uporedi rezultate sa rezultatima dobijenim $\mathrm{u}$ drugim državama, kao i da predloži eventualne moguće upravljačke mere. Podaci su prikupljeni anketiranjem 177 osoba u licenciranom centru, u najvećem gradu u Metro Manili. Logistička regresija je korišćena za predviđanje verovatnoće saobraćajne nezgode na osnovu promenljivih koje su razmatrane u modelu. Utvrđeno je da su tri promenljive imale značajan uticaj na predviđanje saobraćajnih nezgoda sa motociklistima: starost, ponašanje vozača tokom vožnje i tip raskrsnice. Utvrđeno je veće učešće mlađih vozača u saobraćajnim nezgodama. Značaj starosne dobi je bio neočekivan, a s' obzirom da slični modeli nisu ukazivali na značaj ove promenljive. U radu je pokazano da ponašanje tokom vožnje, konkretno, činjenje prekršaja ima uticaja na nastanak saobraćajne nezgode. Vožnja T i Y raskrsnicama takođe utiče na predviđanje saobraćajnih nezgoda sa motociklistima. Na Filipinima je utvrđen jedinstven skup promenljivih na osnovu koga je moguće predviđati nastanak saobraćajnih nezgoda sa motociklistima. Iako su prethodna istraživanja ukazala na uticaj ovih promenljivih na nastanak saobraćajnih nezgoda sa motociklistima, u radu je utvrđen značaj kombinacije sve tri promenljive. Rezultati istraživanja u pogledu ove tri promenljive mogu poslužiti upravljačkim strukturama u cilju usmeravanja neophodnih mera.

Ključne reči: saobraćajna nezgoda sa motociklistom, psihofizičke karakteristike vozača, faktori okruženja, logistička regresija. 